\title{
Leonese Migration and the Role of Migrants in Acculturation Processes: A Historical-ethnographic Approach to the Case of Val de San Lorenzo (León, Spain)
}

L'émigration à León et le rôle des migrants dans les processus d'acculturation: une approche historico-ethnographique pour le cas du Val de San Lorenzo (León, Espagne)

Emigración leonesa y el papel de los emigrantes en procesos de aculturación: un acercamiento histórico-etnográfico al caso de Val de San Lorenzo (León, España)

Pablo Alonso González and Juan-Miguel Álvarez Domínguez

\section{(2) OpenEdition}

\section{Electronic version}

URL: https://journals.openedition.org/remi/7124

DOI: $10.4000 /$ remi. 7124

ISSN: $1777-5418$

\section{Publisher}

Université de Poitiers

\section{Printed version}

Date of publication: 1 January 2015

Number of pages: 121-147

ISBN: $979-10-90426-24-5$

ISSN: 0765-0752

\section{Electronic reference}

Pablo Alonso González and Juan-Miguel Álvarez Domínguez, "Leonese Migration and the Role of Migrants in Acculturation Processes: A Historical-ethnographic Approach to the Case of Val de San Lorenzo (León, Spain)", Revue européenne des migrations internationales [Online], vol. 31 - n¹ | 2015, Online since 01 January 2018, connection on 15 April 2022. URL: http://journals.openedition.org/remi/ 7124 ; DOI: https://doi.org/10.4000/remi.7124 


\title{
Leonese Migration and the Role of Migrants in Acculturation Processes: A Historical-ethnographic Approach to the Case of Val de San Lorenzo (León, Spain) ${ }^{1}$
}

\author{
Pablo Alonso Gonzáles ${ }^{2}$ \\ et Juan-Miguel Álvarez Domínguez ${ }^{3}$
}

\section{Introduction}

"In order to prevent the British or their insurgent colonists settling in

San Julian's Bay or on the coast to fish whales in those waters, activity to which they have devoted much effort, the King has resolved, in agreement with the viceroy of those provinces, that the formal settling of population in the Bay of San Julian has to be projected and carried out as soon as possible" (Apolant, 1968: 63)

"One of the first to leave the village has been Don Santos, as he is affectionately called in the village. Back in 1866, a young lad, bright-eyed, and with a lot of Don Quixote, announced to the astonishment of all, that he was leaving to American

1 Acknowledges to José Manuel Sutil, Head of the Diocesan Archive of Astorga; to Barry O'Connell and Lea Barreau-Tran for their comments; to the people from Val de San Lorenzo, in Spain and abroad.

2 PhD Candidate, University of Cambridge (United Kingdom), and Postdoctoral researcher at the Institute of Heritage Sciences (Incipit-CSIC). Avenida de Vigo s/n, 15705 Santiago de Compostela, Spain; pa332@cam.ac.uk

3 Researcher, Universidad Nacional Educación a Distancia, Zamora regional branch, Edificio Colegio Universitario, Calle San Torcuato, 43, 49014 Zamora, Spain; jmad1789@gmail.com

4 Apolant references this Royal Decree dated February 24, 1778 as the beginning of a series of legal texts by which Carlos III promote the settlement of Spaniards in the area described. These settlers came fundamentally from the areas of León, Asturias and Galicia (Apolant, 1968: 74). Regardless of the number of maragatos in these travels, their name has remained linked to the belt of the Patagonian coast settled during the reign of Carlos III. The clearest cases are those of El Carmen de Patagones in Argentina and San José de Mayo, whose inhabitants are called maragatos. 
lands, (...) the young Santos embarked at Coruña, bound for America, having landed after several months in the port of Montevideo, a few months later the first (sic) news of the emigrant was received, news that traveled around the village, in which he announced he had arrived with health and was quite happy, leading many parents to make every effort to send their children to South America rather than Cuba as they had formerly thought"

(Anonymous, 1929) 5 .

These two excerpts come from texts that could be considered the founding myths of the migration of people from Val de San Lorenzo, Maragatería - the area where Val de San Lorenzo is located - and León to South America. They also reflect very different historic eras. The former text corresponds to the last decade of the reign of Carlos III, a period in which Spain was a weak power in the international context, but was still capable of expanding to the north and south of its vast empire. The second text comes from the last third of the nineteenth century, when Spain's possessions and its geo-strategic and economic role worldwide had been reduced to a minimum. To this we must add the problems derived from an extremely turbulent century, fruit of the revolutionary changes taking place in the political, economic and religious spheres in Western Europe.

Also, the two texts differ in nature, as the Royal Order corresponds to a legal provision issued by the royal authority of Carlos III, while the second, a newspaper article, is written by a valuro - the name given to the inhabitants of Val de San Lorenzo - who emigrated to South America, in which he recalls a story preserved by oral transmission in his home village back in Spain. The first fragment can be considered a traditional source of the discipline of history - legislative texts - while the second - oral transmission, traditions, and local myths - falls within the scope of anthropology and ethnography - although historians have been doing oral history in recent times as well. We have aimed to maintain a dynamic relation between the social sciences and the humanities in the present study, both in our methodologies and scope.

\section{Geographic and Historic Context}

The Maragatería is a county located in the center-west of the province of León, northwest of the Iberian Peninsula. This geographic and human area of Spain comprising Asturias, Galicia and León shares clear historic, economic and social affinities. Despite the different chronological, regional and local variations, the region underwent the deepest process of emigration to Latin America, and especially Argentina, of the whole of Spain. Even though there are gaps and mismatches in the national statistical series of emigration, the quantitative relevance of the phenomenon is evidence in most analysis at provincial levels.

The county of Maragatería is not an exception to these migration patterns. Its territory covers approximately $400 \mathrm{~km} 2$ and includes the municipalities of Lucillo, Luyego, Santa Colomba de Somoza, Brazuelo, Santiago Millas, Val de San Lorenzo and the old council of Castrillo de los Polvazares which is now in

5 References made to the Revista del Centro Val de San Lorenzo en Buenos Aires will include as much information as provided by the journal. As it is an informal journal edited and published by Spanish migrants in Buenos Aires, it does not always provide author's names and page numbers. 
Astorga. The first four municipalities are mountainous, nestled on the eastern slopes of the 'Montes de León' range, while the altitude and slopes ease gradually as they approach the town of Astorga and move away from the peaks of the Teleno Mountain. Specifically, the village of Val de San Lorenzo is head of a municipality, since the mid-nineteenth century, of $49.5 \mathrm{~km} 2$ comprising the villages of Val de San Román and Lagunas de Somoza.

Economists and historians have always defined Maragatería as a poor area in primary sector resources. This structural deficiency led to an economy based on subsistence agriculture and farming (Alonso Luengo, n.d.; Luengo, 1994). Also, written records show how this condition drove many people to specialize in other trades. Mule driving is the best known and most important of them all. This is cause and consequence of an abundant literature that mixes romance, folklore, legend and history of the maragato people, who were for a long time considered one of the 'cursed peoples' of Spain (Jovellanos, 1782). However, the fundamental economic activity in Val de San Lorenzo was not mule diving but textile production. In fact, at least since the nineteenth century, the village has been the main center of textile activity in the province of León and one of the most renowned of the Spanish northwestern area.

By the mid-eighteenth century, and according to Concha Casado's reading of the Ensenada Cadastre, the place had 221 dwellers, 81 of which "were cloth manufacturers, (...) 155 people were engaged in combing and carding wool (including cloth manufacturers) and 26 women were spinning" (1998: 7-8). About a century later, Madoz notes that "the majority of the population of this village live on this industry [textile], an industry so mean in its productivity that makes this village the poorest in the Maragatería (sic): many families engage in carding and spinning wool for the manufacture of coarse cloth sold at modest prices" (1991 [1845-1850]).

Clearly, this specialization and meager productivity would have a decisive influence on the output of migratory flows to South America (Alonso González, 2009: 177-8). This is so because the cloth industry underwent significant imbalances in the chains of supply-demand leading to transient crises every few years. In times of crisis and unemployment, emigration was a way out for many people. Drawing on the support of family and friends, both in the village or already settled in America, they bought ship tickets and embark to America in the Galician harbors of Vigo or La Coruña. Val de San Lorenzo and Maragatería experienced a huge demographic drain during the first decades of the twentieth century, especially if compared with other counties of the province of León.

Demographic loss in the Maragatería clearly outweighs any other county in the province. Losses are above $10 \%$ in all municipalities, and in four of them one in three people left the area between 1900 and 1930. This situation must be framed in a context where the population of the province of León as a whole increased over $14 \%$ in the same period and the Spanish population grew $27 \%$, despite the strong emigration outputs and the flu epidemic of 1918. Of the fifteen municipalities of León experiencing losses over 16\%, six are in Maragatería. In terms of population loss, the villages of Santiago Millas, Santa Colomba de Somoza, Rabanal del Camino, Brazuelo and Val de San Lorenzo, are placed first, third, fourth, sixth and eighth, respectively, among the 236 municipalities of 
the province. Overall, the area went from 14,524 inhabitants in 1900 to 11,219 in 1930 , a decline of almost $23 \%$. In this case the figures speak for themselves.

Figure 1: Comparative demographic evolution of Val de San Lorenzo starting from 'Value 100'

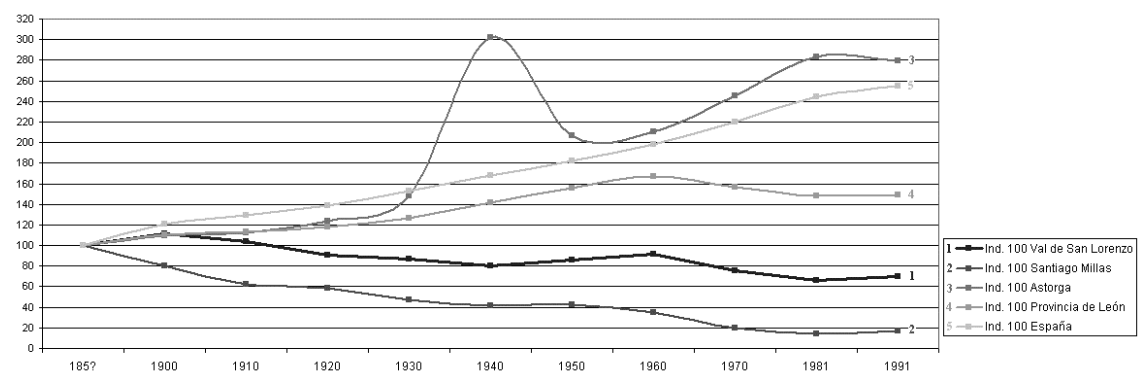

Legend: Data from Val de San Lorenzo are compared with the national and provincial evolution, with the largest town in the area called Astorga, and with another maragato municipality called Santiago Millas.

Source: Figure elaborated by the authors drawing in censuses and gazetteers of the XIX and XX centuries. Data from the 1850s come from an anonymous author (1863).

The severe depopulation during the end of the nineteenth century and the first decades of the twentieth century was mainly due to the disintegration of the economic model based on mule driving. This was the real economic engine and source of wealth in the region (Rubio Pérez, 2003). However, it could not endure the expansion of the Spanish rail network, which put an end to their businesses and also to the transit of Galician peasants through the Camino Gallego6. The line connecting Galicia and Madrid via the province of León, and stopping in nearby Astorga, was inaugurated in 1883. As early as the eighteenth century, several elite families had already migrated to other areas of the Spanish territory where they created new businesses. In particular, they specialized in fish markets and sectors such as traffic control and marketing of these goods all the way between the Galician coast and the great market of Madrid (Rubio Pérez, 1995: 156-157; Sutil Pérez, 2000: 97-98).

When the mule driving economy declined and finally collapsed, these maragatos present in Madrid, La Coruña and other towns in Galicia, León and Castile set off the migration chains, taking family and neighbors to work with them or helping them travelling to South America, especially Cuba, Mexico and Argentina (Da Orden, 2000: 397-418; Marquiegui, 1992). Furthermore, railways facilitated emigration by significantly reducing the journey from León to the Galician harbors. Val de San Lorenzo took part in these migration chains for different reasons: although a mule driving economy did not exist, the relentless

6 The 'Camino Gallego' was the pathway followed by Galician peasants in their way to Castile, where they carried out agricultural seasonal works. Due to the intense comings and goings throughout the Camino of Galician people, the most active group in the emigration flows of the time, ideas and myths about migration and 'the Americas' were widespread in villages located along the way such as Val de San Lorenzo. 
industrialization process and its transient crises in the village were the breeding ground for emigration.

Figure 2: Comparison of the demographic evolution of the various municipalities of León in the opening decades of the XX century

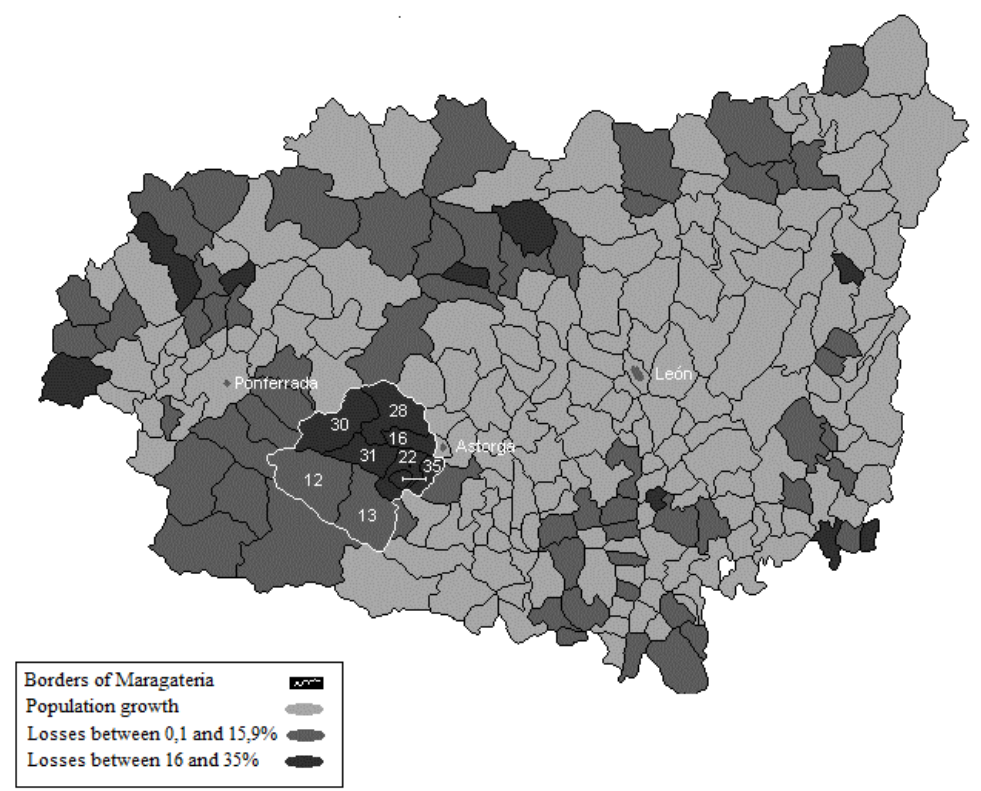

Sources: Dirección General del Instituto Geográfico y Estadístico (1904) Nomenclátor de las ciudades, villas, lugares, aldeas y demás entidades de población de España formado por la Dirección General del Instituto Geográfico y Estadístico con referencia al 31 de diciembre de 1900 / Provincia de León, Madrid, Imprenta de la Dirección General del Instituto Geográfico y Estadístico.

Dirección General del Instituto Geográfico y Estadístico (1933) Nomenclátor de las ciudades, villas, lugares, aldeas y demás entidades de población de España formado por la Dirección General del Instituto Geográfico, Catastral y de Estadística con referencia al 31 de diciembre de 1930 / Provincia de León, Madrid, Hijos de M. G. Hernández.

Once the first migrants settled down and acquired a certain financial stability in America, they started helping brothers, cousins, children and friends, providing them with passage onboard transatlantic crossings, employment and social integration in the host nations (Da Orden, 2005). 


\section{Brief Historiographical Review of the Topic of Emigration in León and Maragatería in the Contemporary Era}

Emigration was one of the cardinal events of the last century in the province of León. Understanding emigration and its phenomenological, emotional, economic, and political causes, along with the impact that returned emigrants had in their home communities, is fundamental to understanding the recent history of the region. Unfortunately, this is one of the many facets of the contemporary history of León where questions still clearly outweigh the answers, and huge gaps in the historical and anthropological knowledge exist.

This situation stands in stark contrast with the neighboring regions of Asturias and Galicia, where emigration is a well-researched and well-known historical phenomenon. Museums, academic and outreach publications, and talks spread the awareness of the issue to a wide audience, emigration being linked in some cases with the construction of regional identities and the volkgeist of the people. In contrast, the history of thousands of Leonese emigrants has yet to be written. In Leonese society, there does not exist an awareness of the significance of emigration. Migrant people and their individual and collective existence are bound to family memory, some street inscription recalling their patronage in public and religious works, and hundreds of unrelated and partial notes spread in newspapers, magazines and on the internet. To this we can add some books and articles written by local, informed people pointing to those who excelled in their host countries, or reinstating the knowledge acquired in local communities and transmitted orally, affirming vaguely that 'many people left' for Argentina, Cuba, or other Spanish regions. The trauma that the emigration process inflicted has been covered under a thick veil of public and institutional oblivion. It is not that Leonese people have asserted a 'triumph over the past' as in the Galician case (González Ruibal, 2008: 134). Rather, emigration simply does not exist as a social phenomenon and is not present in the public sphere.

In terms of academic production, there are not many works addressing the issue of emigration focusing on Leonese natives. In fact, most studies accounting for Leonese migration have been carried out from the Argentinean perspective and written records, such as the works of Ana de Francia (1988: 3-28), Blanca Zeberio (1994: 409-438), Maria da Orden (2005) or Sergio Maluendres (1994: 449-480).

A larger number of investigations have framed Leonese migratory patterns within the political and geographical context of the migrations of Castile and León. In this field, Juan Andrés Blanco has been the most prolific scholar (Coralia, Alonso and Juan Blanco, 1993; Llordén, 2008; Ordóñez, 2011), along with Coralia Alonso (1996) and Eugenio García Zurdo (1983). The collection of oral testimonies of emigrants has been addressed by Guillermo Pilía in an edited book (VV.AA., 2005) and by M. A. Viguera in his PhD dissertation (2003).

With regard to associations of regional Leonese origin in America, we can highlight again the work of Juan Andrés Blanco on the Leonese Colony in Cuba (1993, 2005, 2006), Verónica Ordóñez on the Leonese Group in Mexico (2011) and Juan Álvarez on the Leonese Center in Buenos Aires (2002, 2004). With regard to 
the area of Maragatería, Matías Rodríguez in his Historia de Astorga dating from the beginning of the twentieth century devotes a chapter to the maragatos in America (1909: 682-692). Ricardo García's Por tierras maragatas (1955) provides some useful information and accounts about emigrates from the area. His insights are especially relevant for the study of people from Val de San Lorenzo settled down in Argentina and Cuba, and the associations created by them: the Centro Val de San Lorenzo de Buenos Aires and the Sociedad de Naturales de Val de San Lorenzo en La Habana.

Furthermore, the works of Jesús Paniagua (2000: 115-132) and Laureano Rubio (1991, 1995; 2003: 115-132) address the emigration of maragatos and Leonese people to América. However, their accounts focus primarily on the modern era. In turn, Luis Alonso Luengo, former chronicler of Astorga, published several articles in local and provincial newspapers on the topic, which have been compiled in his book Los Maragatos (1981). He centered his attention on the presence of maragatos in the cities of Carmen de Patagones (Argentina) and San José de Mayo (Uruguay). Martín Martínez, his successor as chronicler of Astorga, has focused on the biographies of some outstanding individuals, for instance, in the life of the maragato Matías Alonso Criado, who participated in the commemoration of the IV Centenary of the Discovery of America in Uruguay in 1892 (Martínez, 1992). The connection between the foundation and history of Carmen de Patagones and the maragatos, has been explored by Miguel Peña (2005). Concerning Val de San Lorenzo, the most significant study hitherto is provided by Etnoarqueología y gestión del patrimonio cultural of Pablo Alonso, who devotes a chapter to the topic (2009).

The Center Val de San Lorenzo in Buenos Aires provided a sort of self-history in different articles published in the journal of the group (De Abajo, 1950). Finally, a wide range of professionals from different fields and disciplines - architects, journalists, writers, religious, informed locals, etc. -have engaged in the study of and provide data about the emigration of maragatos to America, such as José Manuel Sutil, Juan Óscar Otero, Julio Carro, Máximo Palacio, Juan Pedro Vera, José Antonio Carro and Juan Carlos Villacorta.

\section{The 'Centro Val de San Lorenzo' in Buenos Aires: Historic Synthesis (1924-1940)}

The most significant collective action carried out by the valuros in Argentina was the foundation of the Center in Buenos Aires. This kind of local association is rarely found among other groups of Spanish emigrants in Argentina, and is without doubt the most important both qualitatively and quantitatively of all the groups of local/county scope created by the Leonese in America. The foundation dates back to 1924. In September 1926, the Center started publishing a journal of the same title. This publication and the anthropological study carried out by one of the authors from 2006 until 2012, provide the fundamental data for the present study. The journal is the most relevant periodical publication produced/written for and by valuros in Spain and Argentina during the whole twentieth century. It was published more or less on a regular basis between 1926 and 1935 (eight issues), providing a basis of communication and updating between those who stayed in Val de San Lorenzo and those who emigrated. Essentially, the bulletin 
presented the births and deaths on either side of the Atlantic, quotidian affairs of people and significant events such as marriages, as well as opinion pieces normally focusing on the potential for improvement and transformation of the home village. The journal was distributed among the partners of the Association in Buenos Aires and then sent to the families or friends back in Val de San Lorenzo, as well as to other migrants established in Cuba, Santo Domingo or Mexico (Anonymous, 1929, 1975).

\section{Origins and Birth}

Ricardo García situates the origin of the Center in the communities of valuros rooted in Santos Lugares ${ }^{7}$ and Buenos Aires (1955: 223-4). These people shared a common root and a sense of community, but more importantly, they were interested in meeting to practice sports and to discuss politics. Their favorite sport was the bolos maragatos (maragato bowling). Politically, they supported the left-wing Círculo Republicano (Republican Circle) which had been established in their home village in a period of political turmoil in Spain (see Preston, 2001). According to the Memorandum written by the secretary of the society, the Center was officially established in the city of Buenos Aires on 18 May, 1924, in a "meeting celebrated in the house of Juncal Street, 2100, offered by one of our enthusiast fellow countrymen" (Secretary, 1926). The members agreed that the main purposes of the society would be to "serve as a link between the people from the aforementioned village wherever they resided in Argentina and, on the other hand, to be supportive of the public instruction in Val de San Lorenzo" (/dem). Finally, a commission was appointed to draw up the constitution of the society ${ }^{8}$.

After an intense recruiting campaign amongst the valuros settled in Argentina, the 15th June 1924 the head office of the Center finally hosted the first General Assembly, where the statutes were approved and a directive commission was appointed. In this same report a brief review is made of the activities carried out by the society at that point - two years and three months after its foundation. The secretary highlights three basic tasks. First, the relief and support provided to the sick, the covering of burial costs, and the protection of those who had fallen into destitution and beggary. The second aspect concerned support provided to the education system and the students in Val de San Lorenzo. Finally, the third task involved the funding of parties and a playing field for the maragato bowling game.

\section{Quantitative Evolution of the Membership (1926-1940)}

When evaluating the number of members of the organization the first thing to consider is that the three censuses of the home village for the interval 1920-1940 show an average for the period of 760 inhabitants. In turn, the evolution of the membership of the Center in Buenos Aires is as follows: in 1926 there were 103 affiliates (Anonymous, 1926), the same as in 1928 (Anonymous, 1928b). In 1933 the number reaches 129 (Anonymous, 1933b), falling to 87 in 1939

\footnotetext{
7 This locality is currently comprised in the conurbation of Great Buenos Aires, in the Tres de Febrero District, west to the capital.

8 The commission was composed by Román Cordero, Cesáreo Pérez, Manuel de Cabo, Pedro Matanzo, Gabriel Franco and Santiago Abajo.
} 
(Anonymous, 1940b). However, the constant recruitment campaigns show that the number of valuros in Buenos Aires must have been much higher than that. Seemingly, the number of members grew considerably in the following years ${ }^{9}$. Among other reasons, the increase was due to the building of a new headquarters in the capital (Jaramillo Street, $n^{\circ} 3067$ ), and because the society integrated the descendants of the members born in Argentina. This fact, along with the magnificence with which life of the valuros in Buenos Aires was portrayed in the journal, led many people in Val de San Lorenzo to believe that there were more compatriots "allá que acá", literally "there than here", as ethnographic interviews show.

The new headquarter of the society was inaugurated the 13th February, 1944. According to Santiago de Abajo, one of the most active members of the society, the acquisition of the land and the building of the house "was the outmost prize achieved after all the effort. This is the greatest success in twenty five years" (De Abajo, 1950).

Concerning issues of gender, the data show that the percentage of male members always outweighed that of females. In particular, in 1926 and 1928 women represented $18.4 \%$, increasing to the $24 \%$ in 1933 and falling to $18.4 \%$ again in 1939. Clearly, this fact is related to the prevailing machismo in the group, whose fundamental activities - sport and politics - were considered to be suitable for men exclusively.

The propaganda to attract more valuros living in Argentina to the Center remained one of the fundamental pillars of the directorship's policies: the journal is filled with calls to join the society and accusations of 'a lack of patriotism' referring to the sense of 'local allegiance' rather than to a sort national identification at the Spanish level- aimed at those who had not yet joined. In the first issue of the journal, the so-called ' $X$ ' concluded his article on mutualism adding that "there is nothing else for me to do than call the sons of Val de San Lorenzo to join our ranks as it is a human duty to do so" (Anonymous, 1926b).

Occasionally, calls for affiliation were tinged with a certain air of rebuke and with comparisons with other regional collectivities more prone to associate: “We very sincerely regret that not all children of Val de San Lorenzo belong to the Center, and we regret it because we do not see the reason for such indifference towards an institution that could very well do so much good on behalf of each and every one of the sons of our village. What are the reasons to refuse joining the Center? We ignore it. Are we less capable than the children of Galicia?" (Anonymous, 1928d). In 1931, the president gave a warning to his fellow compatriots "in order for them to line up around our center" (Ares, 1931). The topic came to be the subject matter of the editorials of the journal. For instance, in 1935 the editorial ends "reminding the sons of Val in Buenos Aires that there is a society where everyone must be enrolled, and we regret the indifference of some, the inattention and disrespect of others, and value the contribution and support of our members" (Editorial, 1935).

9 According to indirect sources, the Center reached 172 associates during the 1950s (García, 1955: 226) and 400 during the 1960s (Anonymous, 1961). 


\section{Patronage Work}

One of the basic aims of the society from the very beginning was to carry out patronage work with the home village. In fact, the statutes devote one chapter to the issue ${ }^{10}$, focusing on three fields: contributing to public education, helping the needy, and making donations to people affected by disasters of all kinds (Anonymous, 1926). In a brief article, Santiago de Abajo clarifies the intentions of the migrants: "our home village needs a building to shelter the 160 students of both sexes, half of which, by official regulations, were not receiving primary education in municipal schools, and thus their education had to be paid for by parents who hired private tutors". Because of this, at the general meeting on April 18, 1925, it was firmly agreed that "the Centre Val de San Lorenzo in Buenos Aires may not invest in any other social activity ... until a building for schooling is constructed and funded by the Center" (De Abajo, 1950). Finally the national and local authorities provided a solution for the poor school infrastructure. However, the members of the Center continued their campaign in support of education: in 1928 they established Incentive Awards to the best students in Val de San Lorenzo (Anonymous, 1928c).

One of the most ambitious projects was the construction of a public laundry to ease the cleaning activities of women during winter time. The laundry was to be located in the banks of the riverTurienzo and close to the Park Pedro Alonso. Apparently, the work was hampered with difficulties, accumulating several delays to the initial estimates of its promoters. Soon before its inauguration, it was destroyed, in February 1935, "due to the extraordinary force of the current of the river; no one in the place remembers a similar flooding..." (Franco, 1935: 45) A report, in 1935, estimated the losses to be 9000 pesetas - a considerable amount. Still in 1950, Santiago de Abajo complained that the "authorities, neighbors and local institutions [in Val de San Lorenzo], facing the lack of a public good [the laundry] should have cooperated in some way with our Center to rebuild it" (De Abajo, 1950: 5).

Other initiatives set out by the associates towards the village in 1926 were the fundraising campaigns to donate money to the needy and to provide different materials to the schools of Val de San Lorenzo (Matanzo, 1928). Again, in 1927 a higher amount (seventy one Argentinean pesos compared to the previous seven pesos) went to the "needy and students of Val de San Lorenzo" (Andrés, 1928). The journal of 1928 proposed to fund a gravestone to the memory of Gregorio Cordero, sheriff of the court who had been buried in the Civil Cemetery due to the refusal of the parish priest to bury him on sacred ground in the Religious Cemetery (De Cabo, 1928). This clearly shows that the involvement of the Center in political issues in Val de San Lorenzo started well before the politically turbulent period that followed the declaration of the Second Republic in Spain (1931).

The same year a subscription was opened to raise funds to embellish the area of El Gatiñal (Anonymous, 1928a). In order to promote communication between the children in both sides of the Atlantic, the society decided in 1929 to hold a competition of children's stories with two prizes "for the best story from

10 Chapter 9, articles from 51 to 53. 
the students in Val de San Lorenzo on the topic of 'Customs of the village', and a similar reward 'for the best story of customs from Buenos Aires'" (Director, 1929). In 1933 the society sent a petition to the Ministry of Public Works of the Spanish Government asking for the continuation of the "road which, starting from Astorga (León), reaches Val de San Lorenzo" (Cordero, 1933). Of course, apart from the activity of the Center, we should add to this list the material assistance of the emigrants to their friends and families, which surely improved the quality of life of people in the home village.

\section{A Mutual Aid Center}

In a similar vein to other migrant communities, one of the primary purposes of the association was mutuality, that is, the provision of economic and social assistance for those members who, due to illness or accidents, could not work and survive in the host country. Moreover, the statutes took into account contingencies such as covering the costs of hospital stays or the funerals of those without resources (Anonymous, 1926b). Mutual aid societies in which the reasons for solidarity were found in a shared origin - lazos de paisanaje or 'fellow countrymen bonds' - and not only in issues of class or social rank, were common among the Spanish migrants in America. For Llordén, the "authentic expansion of Spanish associations will occur fundamentally through the figure of the mutual aid societies and will be delayed, however, until the arrival of the large contingents of emigrants" (2008: 66).

The financial accounts published in the magazine show that aid provided to partners only appears in 1926 and 1927, which are respectively 67.50 pesos to provide a grant to a member and 45.00 pesos paid to an ill member. The balance sheets of 1926 and 1927 reveal that the main source of funding for the society was membership fees, respectively 975 and 1104.50 pesos. Accordingly, subsidies to members accounted for $7 \%$ and $4 \%$ of the total budget. In all other annual budgets aid to members is lumped together with other items or is simply not mentioned.

\section{The Center Val de San Lorenzo and the Valuro and Maragato Identities}

The issue of identity has to be articulated in a paradoxical twofold way. Thus, if on one hand the Center performed an important role in asserting the maragato and valuro identities, on the other the dissemination of its own magazine and the seasonal or permanent return of migrants involved the dissolution of the vernacular identities. This process of 'modernization' was more intense and quicker in Val de San Lorenzo than in any other village in the surrounding area. Most of these changes can be analyzed through the anthropological and material culture study of Val de San Lorenzo and Maragatería, while the written records proved useful as auxiliary sources. First, it should be noted that maragato culture presents a well-defined personality and differential consciousness in León and northwest lberia. These differential traits were not only acknowledged by other neighboring people, but also by European travelers during the nineteenth century such as Richard Ford, George Borrow, Jean-Charles Joachim Davillier or the illustrator Gustave Doré (Casado and Carreira Vérez, 1985; Casado and Vérez, 1992; Escudero and García-Prieto, 1984: 154-157, 170-174, 191-197 and 258-262) 
and Spanish writers (Espina, 1920). This specificity stems from several factors which fall beyond the scope of this paper.

In any case traditional religious cultural practices (pilgrimages and festivals to worship the Virgin of Carballeda) and recreational pursuits (bowling, music and instruments such as whistles and drums), along with their distinctive clothing were still very much present among migrants to Buenos Aires. However, the endurance of the maragato culture upon arrival in Buenos Aires has to be framed in the sphere of performance and representation, while the fundamental traits of the maragato lifestyle were abandoned. Clearly, this transition from 'ritual' to 'exhibition/spectacle' (Handelman, 1997) signaled a rupture and was perceived by them as a symbol of modernization which involved the shift from an implicit cultural identity to the rational representation and affirmation of such an identity: they were rewriting their own history in a sanitized way (Trouillot, 2012). This metacultural position so characteristic of modern and rational mentalities endowed them with a position of symbolic power over the home community. The affirmation and exhibition of the maragato identity in the journal responds in part to nostalgia and partly to recriminations from neighbors of Val de San Lorenzo accusing emigrants of having relinquished their roots.

The first celebration of the Carballeda Virgin festivities recorded in the pages of the bulletin took place on 11 September, 1926 in the new hall of the Center of the Leonese Region. After a comedy performance enlivened by the "vibrant sounds of the maragato drum", they moved to the "classic and unforgettable regional dances" (Anonymous, 1927b). In the celebration of the Carballeda in subsequent years, secular entertainment consisting of the performance of plays, recitation of poetry, comedy acts, and traditional and modern music, prevails over the religious aspects in clear contrast to the intense spiritual character of the maragato culture and celebrations. The secularization of a religious holiday and celebration is clearly related to the predominance of a socialist ideology among the members of the society. Most of them were part of the expanding working classes of the growing metropolitan areas of South American cities such as Buenos Aires, where left-wing ideologies thrived (Halperín Donghi, 1976).

Similarly, the traditional sport bolos maragatos served as an element of community cohesion in Buenos Aires. Already in 1926, long before the existence of the first building owned by the group (1944), championships were held seasonally in the facilities on Colonel Roca Street? (Secretary, 1926). This practice took place for several years and came to establish clear rules and prizes (Anonymous, 1927a). There are also references to the textile identity of Val de San Lorenzo. In most cases, remembrances of textile work and related activities merge nostalgia and relief, highlighting the hardships of the old times. These accounts reached Val de San Lorenzo, where textile activity was still the primary occupation of most people. Letters to families and the journal used to be read in groups, as many people were illiterate due to the flawed education system and to the fact that textile activities required the participation of children from an early age. Of course, the reception of these stories caused unrest and discomfort as people became self-aware of their poverty and backwardness in comparison with the urban life standards of a thriving Argentinean economy. 
Traditional dress is an essential element in the representation and expression of individual identities in society (Tarlo, 1996). The methodologies of visual analysis enabled us to investigate the illustrations of the journal and old photographs collected in the village (Rose, 2001). The pictures published show how emigrants in Buenos Aires avoided using the traditional dress and wore clothes typical of the time in Argentina. Occasionally, and probably purposefully, the images highlighted the predominantly white colors of the emigrants in contrast to the black robes of the traditional maragato dress. The first images portraying emigrants with maragato clothes do not appear until 1931, when some children are represented (Anonymous, 1931: 24, 30). In subsequent years, they are not very common (Anonymous, 1933a). After 1935 there is a change in the tendency: a group of seven males and ten females are portrayed dressing as maragatos. However, this exhibition is related to the celebration of the Day of the Race Bandera de la Raza -, an event which involved other local and county Spanish communities. The issue portrays many other children in traditional dress. Again, the 1939 issue of the journal displays women and children in maragato dress ${ }^{11}$. This highlights the idea that traditional identities had become a joyful game and a rational choice and not a 'cultural given' any more. Only women and children dressed up in traditional clothes: photos always show men wearing a suit, an ideal representation of the autonomous, liberal, individual subject who has overcome tradition. In any case, the decontextualized representations of people dressed in maragato clothes were displayed in a way that emphasized contrast with images of people from Val de San Lorenzo, where 'tradition' was real and not represented. Indeed, tradition was portrayed as something damned to disappearance, as a picture of the journal presenting the last people wearing maragato dress in the village in 1928 shows. In fact, the dress did not fall into disuse until the 1940s.

The bulletin functioned as one of the fundamental devices for the acculturation of people in Val de San Lorenzo, understanding acculturation simply as a cultural change that results from contact between previously disconnected cultures. The vernacular identities resulting from modern processes of subjectivization and individuation (Castro-Gómez, 1996) were partially shattered by the communication with the migrant community through the journal in a twofold way. Firstly, the materiality of the journal and the fact that their compatriots could create and send it from the other side of the Atlantic was shocking. Secondly, with this journal, the members of the society could convey images and discourses which were characteristically modern and which disrupted and overcame the anchors of traditional life: religion, clothing, lifestyle, work and so on. Even the socialist ideology is a product of modernity, although the emigrants framed it in such a way that it seemed the 'natural' continuation of vernacular forms of life based on commonality and the family as the basic unit of economic production. Of course, the whole situation fuelled a desire to migrate to Buenos Aires in the population. Among the 'internal' factors leading to this we could refer to the increasing self-awareness and acknowledgement of poverty, the hardship and meager revenue of textile work, and the sense of humiliation especially for young males - derived from not emigrating, which was regarded in society as a sign of weakness or cowardice. Buenos Aires was depicted as a

11 Three individual portraits and a collective picture (Anonymous, 1940a). 
'paradise' where life revolved around leisure activities. Photographs showed sumptuousness and elegance, a demonstration of the good financial conditions of their compatriots, along with all the possibilities offered by urban and modern life in material terms (fashionable clothes, luxury goods, etc.) and in social terms (parties, different job opportunities, social advancement, detachment from strict religious life, etc.).

Although the journal apparently enhances the distinctive traits of maragato and valuro identities, this is achieved from a metacultural position involving a detachment from that reality. This detachment is characteristic of a modern epistemological position or what Castro-Gómez calls the 'point-zero' perspective (2007), from which the individual is able to 'choose' among the identifications he is willing to ascribe to. Their descriptions visibly exacerbate the hard work they had undergone in Val de San Lorenzo, while their own difficulties in Buenos Aires were hidden. In fact, there are no descriptions of the lives of the members in Argentina: their lives and the hardships they suffered remain concealed. Ethnographic research showed that many people had to come back to the village, either soon after arrival or some years later. Some of the returned people came back as poor as they left, and thus had to rely on familial networks to survive. In comparison, emigrants to Mexico and Cuba made significantly more profits in their host countries, investing in the textile industrial sector when they returned to Val de San Lorenzo.

Similarly, the issue of whether dressing traditional clothing or not became a conscious decision rather than part of everyday life. In other words, wearing certain clothes or not becomes a rational choice. The remystification of the maragato dress through its representation in photographs, whether individual or collective during formal meetings and informal gatherings, is open to a double reading. On one hand, it serves as an identity marker in Argentina, something to be proud of and to wield in the face of other communities (either Spanish, from other nationalities, or to the broad Argentinean society). Likewise, it provided, together with sports and politics, the binding tissue of the valuro community in Buenos Aires ${ }^{12}$. On the other hand, since the journal was sent to people in the home village, it served the emigrants to show their compatriots and family that they had not 'lost their roots' despite their clear embracing of modernity, and that they were 'doing well'. This can be framed as a metaphor of processes of remembering and forgetting (Connerton, 2009), in which not losing the roots meant that they had not forgotten what they had left behind in Val de San Lorenzo: wives, parents, children, friends, and so on.

Issues of gender inequality are made clear in the journal. As mentioned, men are repeatedly represented in positions of dominance as liberal and rational entrepreneurs. Children were dressed as maragatos to show people in the

\footnotetext{
12 "This time we wanted to dedicate the cover of issue to a typical subject of our region, (...) With an ineffable love we evocate and contemplate the severe and arrogant group of maragatos who rallied throughout the Leonese Capital with their traditional dresses, representing the Region during the royal visit to León of Alfonso XIII shortly after his coronation. For us, maragatos who love our tradition and everything which is exclusive heritage of Maragatería (sic), the referred picture is a pure matter of pride, because it represents and is a living witness of what has been, is and will be the noble and strong maragato lineage" (Anonymous, 1940c).
} 
village that they were 'being educated in tradition', creating a symbolic affiliation with the volkgeist of the home village. The subaltern position of women is not only connected to an issue of discourse of representation. Rather, it is quite material: the emigration process normally entailed that husbands and male children departed, leaving their wives and female children behind. Whereas it was common for emigrants to create new families, the position of 'abandoned' women in the home society was weakened and their possibilities of a second marriage were very low. Normally, this implied that female children had to work as maids for the richer families from an early age. While men 'progressed' and advanced socially, women relied on remittances from Argentina - if they were forthcoming - and on menial jobs within the textile production process such as spinning or carding wool. The subaltern role of women could be interpreted as a continuation of previous socioeconomic patterns in the area. Maragato men had been for generations dedicated to mule trade and therefore had higher mobility patterns, while women remained attached to the village and the land properties. When modernization led to the end of mule trade the division remained: men migrated and consolidated migration chains and women stayed, especially during the initial decades of the process. Later on, when women started to travel to Buenos Aires it was normally because their husbands afforded it. This normally implied that they stopped working to be maintained by their husbands and becoming housewives, performing a subordinate role in tune with liberal modern schemes. Nonetheless, our research has documented isolated cases of young women who emigrated alone to work as housemaids, normally in the houses of other migrants - not necessarily their relatives - from their place of origin.

\section{The Role of Returned Immigrants and Material Culture}

This section briefly accounts for the role played out by material culture in relation to the process of migration. More specifically, it looks at the role of returned migrants, which are generally known as indianos - those returning from las Indias - in Asturias or Galicia, but not in León, where they are broadly called as americanos (see Alonso González, 2009). As previously mentioned, the issue remains largely understudied in León in comparison with Galicia or Asturias.

The returned migrants function as catalysts for change (Núñez Seixas, 2000). They actively and passively disrupt the social establishment of the village to which they return, prompting a process of acculturation. Moreover, they become points of reference with which to compare the level of welfare and social rank in the local community (Castro, 1992), thus upsetting the customary social hierarchies. Of course, not all the migrants achieved a similar economic level. In Val de San Lorenzo the wealthiest migrants came back from Cuba and Mexico and not from Buenos Aires. However, even poor returned migrants had a higher rank in the social hierarchy thanks to a particular sort of 'symbolic capital' (Bourdieu and Thompson, 1991): they had traveled, had urban habits, dressed differently, etc. In sum, they 'knew more' (Cardín, 1984). For people in the village they had a different 'air' or 'aura'. This was emphasized by the fact that they brought modern objects with them: clocks, pens, and similar items. While the journal represents a society 'out there' in Buenos Aires where life is seemingly better, 
material culture conveys a direct message to people in Val de San Lorenzo by making them face modernity in their own setting. The existence of 'modernity' implied that there was 'tradition' (Latour, 1993), and tradition came to mean poverty and backwardness.

Thus, the returned immigrant is a fundamental factor in fuelling internal social change in the home society. Referring to the Galician context, González-Ruibal (2003: 39) considers that their political role is generally irrelevant. However, their mere presence in social life has pragmatic relevance in two fundamental aspects. Firstly, they represent the transition from the collective to the individual. Secondly, they sanction a shift in the social role of women, who become passive subjects. Val de San Lorenzo is an interesting case because the migrants were involved in local politics, both in Buenos Aires and after their return, and played a fundamental role in the definition of collective and individual roles and identities. In fact, they had a crucial influence in the forms by which Val de San Lorenzo negotiated the transition from a traditional society into modernity and industrialization (García Canclini, 1989).

The group of migrants in Buenos Aires quickly joined the socialist political circles. This is confirmed by oral testimonies, by the early writings in the magazine (pre-Spanish Civil War, 1936-1939) and by early twentieth century photographs showing returned migrants in Val de San Lorenzo proudly displaying socialist newspapers from Buenos Aires in their headquarters. Their meeting place in the village came to be known as El Mentidero, literally 'The place of liars', which is indicative of the skepticism with which their ideas were met. During the period of sociopolitical turmoil in Spain comprising the Second Republic period (19311936) and the Civil War (1936-1939), the magazine showed a clear inclination to support the republican regime and the republican side during the War. In fact, the end of the War signals a shifting point for the journal, which becomes far less concerned with cultural and sociopolitical issues. After 1939, the journal became a neutral 'register' with the notices of social issues such as births, marriages and deaths, which occurred in both Buenos Aires and Val de San Lorenzo. Despite this fact, oral testimonies confirm that the sole ownership of the journal was a cause for suspicion for the fascist dictatorship's authorities in the early postwar years.

This is not without reason, as in the pre-Civil War era the authors of the journal incite in several texts the people of Van of San Lorenzo to create a communal factory where everyone would have a share (Oriola, 1931). Their ideology tried to naturalize in some way the transition from vernacular forms of communal production and life to a modern productive scheme based on socialist ideology. Indeed, their ideas were implemented before the Center was officially established in 1924. In 1920, a communal factory working with hydraulic energy was built on the margins of the riverTurienzo, and a second one, in this case electrically powered, was inaugurated some years later called La Comunal. The latter factory survived with productive ups and downs and variable participation levels of the communal shareholders until the late 1990s, when it was finally closed down and converted into a textile museum. In any case, the enduring functioning of a communal form of production during the entire dictatorship of General Franco (1939-1975) in an overall conservative peripheral region bounded to tradition and religion is surprising and can only be understood in terms of emigration flows. 
Figure 3: The Mentidero - Place of liars - during the first decade of the XX century

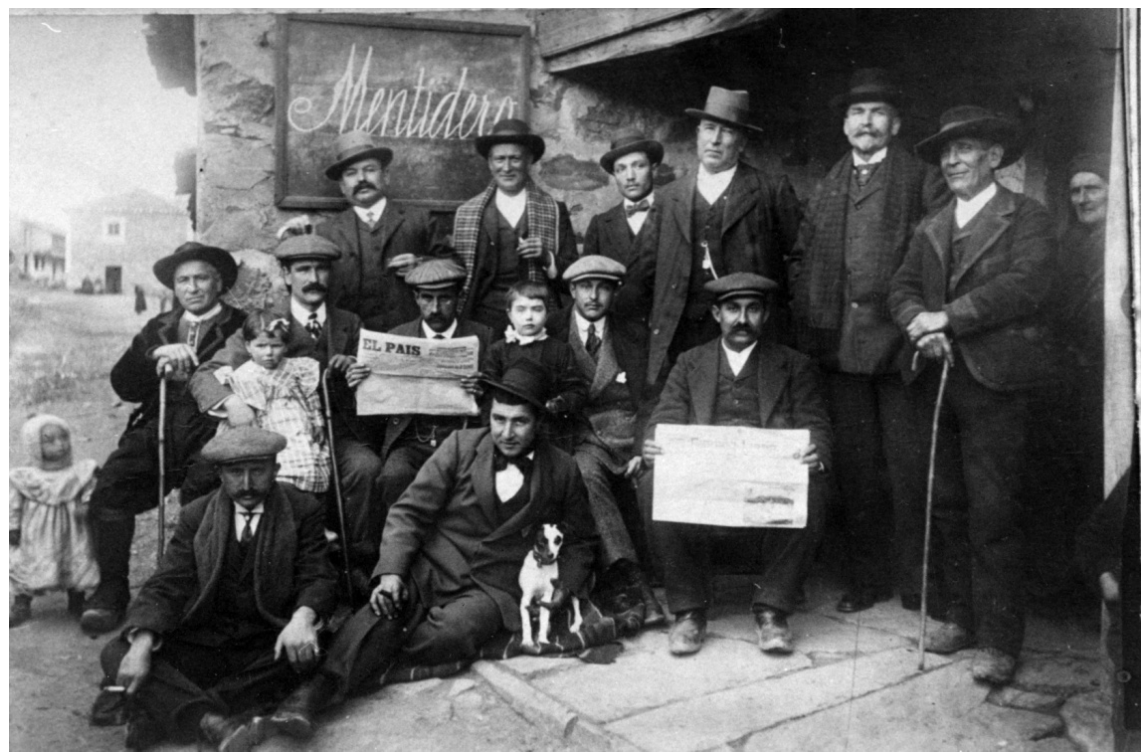

Legend: It was the sarcastic name given by local people in Val de San Lorenzo to the locale where returned left-wing migrants met, a name that was later assumed by the group. The picture shows a clear contrast between the returned migrants wearing modern urban clothes, who can read (and are proud of it), and the person on the left of the picture who still wears traditional maragato costumes.

Source: Personal collection of José Manuel Sutil.

This is not without reason, as in the pre-Civil War era the authors of the journal incite in several texts the people of Van of San Lorenzo to create a communal factory where everyone would have a share (Oriola, 1931). Their ideology tried to naturalize in some way the transition from vernacular forms of communal production and life to a modern productive scheme based on socialist ideology. Indeed, their ideas were implemented before the Center was officially established in 1924. In 1920, a communal factory working with hydraulic energy was built on the margins of the river Turienzo, and a second one, in this case electrically powered, was inaugurated some years later called La Comunal. The latter factory survived with productive ups and downs and variable participation levels of the communal shareholders until the late 1990s, when it was finally closed down and converted into a textile museum. In any case, the enduring functioning of a communal form of production during the entire dictatorship of General Franco (1939-1975) in an overall conservative peripheral region bounded to tradition and religion is surprising and can only be understood in terms of emigration flows.

In contrast, the foundation of the Sociedad de Naturales de Val de San Lorenzo en la Habana dates back to the early 1920s. The members of this society had a significantly higher economic status than migrants to Buenos Aires, and 
were characterized by a liberal and individualistic political ideology that encouraged the creation of private enterprises with a single owner and salaried work. Many factories were created in Val de San Lorenzo in this vein during the first half of the twentieth century with varying degrees of success (Alonso González, 2007). In fact, a returned family from Cuba invested in the construction of large factories where the entire textile industrial production processes where carried out, and based on salaried work rather than familial units of production. In 1917, the same family had already built a house that could be considered the only local example of what would be called in Asturias or Galicia, Arquitectura Indiana (Indian architecture) -the architectural style employed by returned migrants from America in Spain. Without going into much detail to address these issues, it is important to note that housing is directly related to issues of identity, hierarchy, class and economic status (Kus and Raharijaona, 2000).

The house is evidence of the desire of the builders to differentiate themselves from the surroundings and the rest of the community. Internally, the distribution of the house is typical of Cuban homes, with many bays, open spaces and a wide corridor, which clearly contrasts with the austere and solid vernacular architectural tradition adapted to the harsh winters of the area. Externally, the materials employed are valuable and difficult to obtain in the region: granite and bricks instead of shale stone, slate instead of straw or tiles in the roof. Some of the materials were worked by artisans who had just finished the Diocesan Palace designed by architect Antonio Gaudí in Astorga. A plaque with the name of the family and the date of foundation confers individuality to the house, in contrast to the rest of the village where common architectural elements and materials emphasize community and the absence of difference and inequality. The same family built the largest industry of the village following similar patterns: the LIMA S.A. factory.

These changes greatly influenced the daily lives of valuros - in fact, much more than letters or journals arriving from far away Buenos Aires. Their habitus (Bourdieu, 1972) changed, and people gained awareness of their poverty and backwardness in the face of the novelties coming from overseas. Consequently, they tried to imitate the forms and materials of modernity in architecture and dress: cement and brick, along with the suit, became symbols of economic and social status. These processes of cultural change are common in capitalist societies. Bourdieu considers that a fundamental element in the process is the 'demonstration effect': a new scale of values and desires is suggested and finally becomes dominant not through discourses or arguments against the old order, but rather by the arrival of a set of objects and forms of life which are presented in a more attractive way than the previous ones (González-Ruibal, 2003: 49). Thus, it can be said that both the journal of the Center Val de San Lorenzo in Buenos Aires and the returned migrants were crucial vectors of social transformation in the locality. In tune with the prevailing attitude of passive forgetting in the public sphere of Leonese society, the two new local museums do not make any reference at all to the issue of migration. 


\section{Conclusion}

Our research is the first academic historical study of the fundamental aspects of migration to the Americas in Val de San Lorenzo and Maragatería during the early decades of the twentieth century. Furthermore, our study has provided one of the few accounts of Spanish emigration, combining the methodologies of anthropology, material culture studies and history. This inter-disciplinary effort has enabled us to utilize oral, written and material sources to develop a continuous narrative that provides a far more detailed and in-depth understanding of the ongoing processes of social, economic and cultural change in which emigration and return play a crucial role. It also sheds light on the understanding of the present state of things in the village - culturally, politically and socially. We consider the connection between our historic narrations and contemporary contexts to be fundamental. We must not only provide critical accounts of the ongoing production of cultural discourses through publications, cultural policies or musealization or heritagization processes (Smith, 2006), but also facilitate knowledge transfer and render socially useful knowledge produced by the humanities and social sciences.

Although largely absent from the historiography, it should not be overlooked that the flow of migrants from the province of León is the most significant in Spain after Galicia, Asturias and the Canary Islands. Sooner or later, the provincial institutions and society will have to bring to the public sphere this hidden trauma which has been hitherto confined to the familial and individual realm. Our research confirms the hypothesis that within the provincial context of León, the county of Maragatería contributed the most to the emigration flow relative to its overall population. However, none of the museums or publications in Maragatería deal with the issue of emigration. Val de San Lorenzo was the village, which quantitatively contributed most to the process. Fundamentally, this was due to the fact that nearly all of its inhabitants were engaged in textile production. Episodes of Luddism (Anonymous, 10 March, 1908 ; see also Hobsbawm, 1952) could not prevent the arrival of new machines, which made redundant nearly half of the labor force in only a few years. The investigation shows that returned migrants were fundamental catalysts of sociocultural change in their root societies. In the long run, emigration and the communication between the migrant and home communities did not only have an impact on the ways that valuros negotiated and entered modernity - either under a socialist or a liberal organization and ideology -, but also enabled them to create thriving modern industries in a peripheral and mainly agricultural and rural area of Spain. This shows that communication between similar migrant communities in different places - i.e. Buenos Aires and Cuba - and between migrant groups and home communities is non-linear and complex (Kim, 1977). Moreover, meaning and information can be conveyed through different vectors - textual, oral and material - that have to be taken into account and analyzed holistically. Actually, materiality has been overlooked by scholarship despite its huge relevance in conveying meanings and triggering socio-cultural change (González-Ruibal, 2003).

Our research demonstrates that the level of organization and intense activity of the valuro community in Buenos Aires and Cuba was not reached by any other village with similar demographic patterns. This micro-identitary model 
of association implemented by the valuros was common among Galicians and Asturians, but rare among other Spanish collectivities. Moreover, our case demonstrates that the relatively high level of affiliation to the Center was not solely due to the material aspects and benefits provided - mutual aid, unemployment benefits, leisure time, etc. - as other more powerful centers such as the Asturian or the Galician offered better services. Thus, shared cultural and geographical roots prevailed over class and economic issues as determining factors in questions of society affiliation. Accordingly, cultural identity became a fundamental element of distinction and a social marker in the host society. The desire of the community to distinguish themselves from others becomes evident if we consider that the province of León as a whole had another and more powerful migrant social club. This fact did not impede valuros from having a double affiliation to both societies, but they were firm in their desire to preserve the distinctiveness of their identity. We can therefore speak of identity filiations at four levels: the valuro - locality; maragato - county; Leonese - region; and Spanish - nation. Clearly, the valuro and maragato identities are expressed with greater emphasis in the social sphere, but those filiations do not enter into contradiction with the regional and national identifications, but are rather affirmed and meshed together.

Unfortunately, this complex history of heroism, travel, social advancement, familial break up and separation, poverty and humiliation, nostalgia and love, remains concealed in Val de San Lorenzo. Not a single material or discursive reference to emigration can be found in the village, in the form of memorials or books. Neither can we learn about emigration in the museums, which deploy a sanitized lineal story of the technical progress and evolution of industrial textile production that disregards the human dimension: where are emigrants, workers and women? Emigration remains a secret, a burden to be borne privately and bounded to the familial sphere. However, migration is a complex and large-scale process involving thousands of individuals who shared similar experiences, both traumatic and positive, which are better framed and dealt with in a collective mood. Self-memoricide is not the solution. Will people and institutions from León and Val de San Lorenzo acknowledge this fact and act accordingly?

\section{References $^{13}$}

Alonso Coralia (1996) Castellanos y Leoneses en Cuba. Apuntes para una historia, La Habana, Huella.

Alonso Coralia and Juan Blanco (1993) Zamoranos y castellano-leoneses en el Ejército Libertador Cubano (1895-1898), Anuario del Instituto de Estudios Zamoranos Florián de Ocampo, pp. 547-586.

Alonso González Pablo (2007) La Arqueología Industrial en León. Reflexiones apartir de la investigación en el Val de San Lorenzo. Estudios Humanísticos. Historia, 6, pp. 295-315.

13 The 'Revista del Centro Val de San Lorenzo de Buenos Aires' is abbreviated as 'RCVSLBA'. 
Alonso González Pablo (2009) Etnoarqueología y gestión del patrimonio cultural: Maragatería y Val de San Lorenzo, León, Universidad de Léon.

Alonso Luengo Luis (1981) Los maragatos: su origen, su estirpe, sus modos. León, Nebrija. 158 p.

Luengo Ugidos Miguel Á. (n.d.) Maragatería y Cepeda, in Valentín Cabero and Lorenzo López (Eds.), La Provincia de León y sus Comarcas, León, Diario de León, pp. 218-232.

Álvarez Juan M. (2002) "León», una revista leonesa en La Argentina, Tierras de León, 40 (114), pp. 29-53.

Álvarez Juan M. (2004) Leoneses en Argentina. El Centro Región Leonesa de Buenos Aires, Historia, 16, pp. 113-121.

Andrés Braulio (1928) Balance General del Tercer Ejercicio, RCVSLBA, 3, n.p.

Anonymous (1863) Nomenclátor estadístico de la provincia de León, León, Viuda e Hijos de Miñón.

Anonymous (1926) Nómina de socios actuales, RCVSLBA, 1, n.p.

Anonymous (1926b) Mutualismo, RCVSLBA, 1, n.p.

Anonymous (1927a) Gran campeonato individual de bolos organizado por el Centro Val de San Lorenzo, a realizarse en su campo de recreo calle Coronel Roca 1509, RCVSLBA, 2, n.p.

Anonymous (1927b) Nuestras Fiestas / Festejando la Carballeda, RCVSLBA, 2, n.p.

Anonymous (1928a) El Gatiñal y los residentes del Val en Buenos Aires, RCVSLBA, 3, n.p.

Anonymous (1928b) Lista de los socios del "Centro Val de San Lorenzo", RCVSLBA, 3, n.p.

Anonymous (1928c) Los "niños premiados" y "Premios de Estímulo", RCVSLBA, 3, n.p.

Anonymous (1928d) Los paisanos, RCVSLBA, 3, n.p.

Anonymous (1929) Nuestra revista, RCVSLBA, 4, p. 6.

Anonymous (1931) No title, RCVSLBA, 5, pp. 24-30.

Anonymous (1933a) Camisería de Antonio Botas, RCVSLBA, 7, p. 13.

Anonymous (1933b) Nómina de los socios del Centro en Mayo de 1933, RCVSLBA, 7, pp. 16-17.

Anonymous (1940a) NoTitle. RCVSLBA, 9, pp. 28, 30, 32 and 49.

Anonymous (1940b) Nombres y domicilios de los socios con derechos al 31 de Diciembre de 1939, RCVSLBA, 9, pp. 23-24.

Anonymous (1940c) Nuestra Portada, RCVSLBA, 9, pp. 5.

Anonymous (1961) León, , Centro Maragato Val de San Lorenzo, 90, pp. 26-28. 
Anonymous (1975) Bodas de Oro del Centro Maragato Val de San Lorenzo, Buenos Aires, Centro Región Leonesa de Buenos Aires, 253, p. 18.

Apolant Juan A. (1968) Los pobladores de la Costa Patagónica, Boletín Histórico. Estado Mayor General del Ejército - Sección: Historia y Archivo, 116-119, pp. 62-202.

Ares Benito (1931) Toque de atención, RCVSLBA, 5, p. 47.

Blanco Juan Antonio (1993) Leoneses en La Habana en el siglo XX: la Colonia Leonesa de Cuba, Estudios Humanísticos. Geografía, Historia, Arte, 15, pp. 25-54.

Blanco Juan Antonio (2005) Castellanos y Leoneses en Cuba. El sueño de tantos, Valladolid, Ámbito.

Blanco Juan Antonio (2006) Emigración y asociacionismo castellano y leonés en Cuba, Alcores, 1, pp. 169-206.

Bourdieu Pierre (1972) Outline of a Theory of Practice, Cambridge, Cambridge University Press, 248 p.

Bourdieu Pierre (1991) Language and Symbolic Power, Cambridge, Harvard University Press, 312 p.

Cardín Alberto (1984) La urbanización invertida, Indianos. Cuadernos del Norte. Monografías, 2, pp. 136-140.

Casado Concha (1998) Batán-Museo Val de San Lorenzo, León, Instituto Leonés de Cultura. $46 \mathrm{p}$.

Casado Concha and Antonio Carreira Vérez (1985) Viajeros por León: siglos XII-XIX León, Santiago García. 319 p.

Castro-Gómez Santiago (1996) Crítica de la Razón Latinoamericana, Barcelona, Puvill.

Castro-Gómez Santiago (2007) The Missing chapter of Empire, Cultural Studies, $21(2-3)$, pp. 428-448.

Castro Xavier (1992) Influencias americanas en Galicia, in VVAA Eds., GaliciaAmérica. Cinco séculos de Historia, Santiago de Compostela, Consello da Cultura Galega, pp. 45-52.

Connerton Paul (2009) How Modernity Forgets, Cambridge, New York, Cambridge University Press, $156 \mathrm{p}$.

Cordero Román, and Benjamín Martínez (1933) Nuestra petición al Sr. Ministro de Obras Públicas del Gobierno Español, RCVSLBA, 7, p. 15.

Da Orden María L. (2000) Cadena migratoria, familia y pautas de residencia: una nueva mirada a una vieja cuestión. Mar del Plata, 1910-1930, Estudios Migratorios Latinoamericanos, 45, pp. 397-418.

Da Orden María L. (2005) Inmigración española, familia y movilidad social en la Argentina moderna, Buenos Aires, Biblos.

De Abajo Santiago (1950) Veinticinco años, RCVSLBA, 10, pp. 3-8.

De Cabo Antonio (1928) Carta abierta al Sr. Cura del Val de San Lorenzo, don Emilio González Valderrábano, RCVSLBA, 3, n.p. 
De Francia Ana (1988) De León a Iberoamérica: 1880-1930, Tierras de León, 73, pp. 3-28.

Director (1929) Importante, RCVSLBA, 4, p. 44.

Editorial (10 March, 1908) El Pensamiento Astorgano, 642, p: 2.

Editorial (1935) Felicidades, RCVSLBA, 8, p. 3.

Espina Concha (1920) La esfinge maragata, Madrid, Gil Blas.

Franco Gabriel and Santiago Abajo (1935) Memoria del Centro/Lavadero, RCVSLBA, 8, p. 45.

García Canclini Néstor (1989) Hybrid Cultures: Strategies for Entering and Leaving Modernity, Minneapolis, University of Minnesota Press. 293 p.

García Escudero Ricardo (1955) Por tierras maragatas, Astorga, Cornejo. 328 p.

García Escudero Ricardo y Francisco J. García-Prieto (1984) Viajes y viajeros por tierras de León (1494-1966), Oviedo, Saturio. 408 p.

García Zarza Eugenio (1983) La emigración en Castilla y León, Valladolid, Consejo General de Castilla y León. 256p.

González-Ruibal Alfredo (2003) Etnoarqueología de la emigración. El fin del mundo preindustrial en Terra de Montes (Galicia), Pontevedra, Diputación Provincial de Pontevedra. 286 p.

González Ruibal Alfredo (2008) Time to Destroy, Current Anthropology, 49 (2), pp. 247-279.

Halperín Donghi Tulio (1976) ¿Para qué la inmigración? Ideología y política inmigratoria y aceleración del proceso modernizador: el caso argentino (1810-1914), Jahrbuch für Geschichte Lateinamerikas, 13, pp. 437-489.

Handelman Don (1997) Rituals/spectacles, International Social Science Journal, 49 (153), pp. 387-399.

Hobsbawm Eric J. (1952) The Machine Breakers, Past and Present, 1, pp. 57-70.

Jovellanos Gaspar Melchor de (1782) Cartas del Viaje de Asturias, Salinas, Ayalga. $163 \mathrm{p}$.

Kim Yyum (1977) Communication Patterns of Foreign Immigrants in the Process of Acculturation, Human Communication Research, 4 (1), pp. 66-77.

Kus Susan and Victor Raharijaona (2000) House to Palace, Village to State: Scaling up Architecture and Ideology, American Anthropologist, 102 (1), pp. 98-113.

Latour Bruno (1993) We Have Never Been Modern, Cambridge, Harvard University Press, $168 \mathrm{p}$.

Luengo Miguel Á. (1994) La Maragatería y su espacio administrativo. Medio Ambiente en Castilla y León, 1.

Llordén Moisés (2008) El asociacionismo de los inmigrantes españoles en América, proceso formativo y manifestaciones más notables, in Juan Andrés Blanco Ed., El asociacionismo en la emigración española a América, Salamanca, UNED, pp. 51-90. 
Madoz Pascual (1991 [1845-1850]) Diccionario Geográfico-Estadístico-Histórico de España y sus posesiones de Ultramar 1845-1850, Valladolid, Ámbito. 16 vol.

Maluendres Sergio D. (1994) De nuevo sobre las pautas matrimoniales de los migrantes (y sus hijos): Piamonteses y Leoneses en Trenel, Territorio Nacional de la Pampa (1911-1940), Estudios Migratorios Latinoamericanos, 28, pp. 449-480.

Marquiegui Dedier N. (1992) Las cadenas migratorias Españolas a la Argentina. El caso de los Sorianos de Luján, Studi Emigrazione, 29 (105), 69-102.

Martínez Martín (1992) Matías Alonso Criado: un maragato en el IV Centenario del descubrimiento de América, Astorga, Centro de Estudios Astorganos Marcelo Macías. 62 p.

Matanzo Pedro (1928) Balance General delTercer Ejercicio, RCVSLBA, 3, n.p.

Ordóñez Nélida V. (2011) Historia de la Agrupación Leonesa de México (19411988), in Juan Andrés Blanco Ed., La emigración castellana y leonesa en el marco de las migraciones españolas, Zamora, UNED, pp. 275-298.

Oriola Aurelio (1931) Cooperativismo, RCVSLBA, 5, 16-18.

Paniagua Jesús (2000) Una significativa minoría en la revolución federalista de Brasil o Revolución de los Maragatos (1892-1895), Astórica, 19, pp. 287-312.

Peña Miguel (2005) Maragatos en la fundación de Carmen de Patagones, Astórica, 24, pp. 179-210.

Preston Paul (2001) Revolution and War in Spain, 1931-1939, London, Routledge, $318 \mathrm{p}$.

Rodríguez Matías (1909) Historia de la Muy Noble, Leal, y Benemérita Ciudad de Astorga, Astorga, Porfirio López, 337 p.

Rose Gillian (2001) Visual Methodologies: An Introduction to the Interpretation of Visual Materials, London, SAGE, 408 p.

Rubio Pérez Laureano (1991) Estancamiento económico y marginación social en León durante los siglos XVIII y XIX: respuesta emigratoria en La Maragatería y el Alto Bierzo, in Antonio Eiras Roel andand Agustín Guimerá Ravina Eds., La emigración española a Ultramar, 1492-1914, Madrid, Tabapress, pp. 115-132.

Rubio Pérez Laureano (1995) Arrieros maragatos. Poder, negocio, linaje y familia. Siglos XVI-XIX, León, Hullera Vasco-Leonesa, 173 p.

Rubio Pérez Laureano (2003) Los Maragatos. Origen, mitos y realidades, Zamora, Monte Casino, 159 p.

Secretario (1926) Memoria del Centro Val de San Lorenzo, RCVSLBA, 1, n.p.

Núñez Seixas Xose M. (2000) Emigración de retorno y cambio social en la Península Ibérica: algunas observaciones teóricas en perspectiva comparada, Migraciones andand Exilios: Cuadernos de la Asociación para el estudio de los exilios y migraciones ibéricos contemporáneos, 1, pp. 27-66.

Smith Laurajane (2006) Uses of Heritage, London, Routledge, 368 p.

Sutil Pérez José M. (2000) Final de la actividad arriera: la emigración, Museo de la Arriería Maragata "Ventura Alonso Franco", Santiago Millas, Ayuntamiento de Santiago Millas, pp. 97-100. 
Tarlo Emma (1996) Clothing Matters: Dress and Identity in India, Chicago, University of Chicago Press, $320 \mathrm{p}$.

Trouillot Michel-Rolph (2012) Silencing the Past: Power and the Production of History, Boston, Beacon Press, 216 p.

Viguera Revilla María N. (2003) De Castilla-León a México, 1900-1950, Mexico, Universidad Ibero-Americana.

Various authors (2005) Los castellanoleoneses de La Plata, La Plata, Hespérides.

Zeberio Blanca (1994) En torno a los orígenes sociales y las estrategias de emigración: el caso de los leoneses en la Campaña Sur de Buenos Aires (19001930), Revista de Indias, 54 (201), 409-438. 


\section{Pablo Alonso González and Juan-Miguel Álvarez Domínguez}

\section{Leonese Migration and the Role of Migrants in Acculturation Processes: A Historical-ethnographic Approach to the Case of Val de San Lorenzo (León, Spain)}

The study of migrations and the impact of returned emigrants in home societies has been a long-standing topic of scholarship in Spanish regions such as Asturias or Galicia. Despite the region of León presents similar qualitative and quantitative patterns of migration, the process remains largely understudied. This article puts forth a literature review of the scholarship on Leonese migration. It then presents an empirical investigation of the Maragatería area, focusing on the case study analysis of Val de San Lorenzo. Emigration in this village was particularly strong during the late $X I X$ and early $X X$ centuries, which led to the establishment of active migrant societies in Cuba and Argentina. This paper focuses on the society created by the migrant community in Buenos Aires and how their activity catalyzed a process of acculturation in Val de San Lorenzo. This investigation combines the methodologies of history, anthropology and material culture studies in order to gather a wide variety of data and provide a multi-sided perspective of the whole process. Ultimately, our research connects past events with contemporary contexts, highlighting the complex interplay between migrant and home communities and the long-term implications of those interactions.

\section{..: L'émigration à León et le rôle des migrants dans les processus d'acculturation: une approche historico-ethnographique pour le cas du Val de San Lorenzo (León, Espagne)}

L'observation des migrations et de l'impact du retour des émigrés dans leurs communautés d'origine est depuis longtemps un objet d'étude dans les régions espagnoles comme les Asturies et la Galice. Bien que la région de León présente des caractériques similaires à ces deux espaces, ce processus migratoire reste largement sous-étudié dans la région. En premier lieu, cet article présente une revue de littérature des travaux consacrés aux migrations léonaises et livre ensuite une analyse empirique de la région de Maragatería, en se concentrant sur le cas du Val de San Lorenzo. Sur la période couvrant la fin du XIXe siècle au début du XXe siècle, l'émigration a été particulièrement forte dans ce village, conduisant à la création de groupes associatifs de migrants dans les pays d'accueil qu'ont pu être Cuba et l'Argentine. Cet article se concentre sur la société créée par une communauté émigrée à Buenos Aires et sur les dynamiques qui ont mené à un processus d'acculturation dans le Val de San Lorenzo. Cette enquête allie des méthodologies de recherche issues de l'histoire, de l'anthropologie et des études de la culture matérielle afin de rassembler une grande variété de processus et de fournir un point de vue interdisciplinaire sur l'ensemble de ce système. Cette recherche poursuit donc le but de relier les événements passés au contexte contemporain, mettant en évidence l'interaction complexe entre les communautés de migrants et leur village d'origine en Espagne, et les implications à long terme de ces processus migratoires. 


\section{... Emigración leonesa y el papel de los emigrantes en procesos de aculturación: un acercamiento histórico-etnográfico al caso de Val de San Lorenzo (León, España)}

El estudio de migraciones y el impacto de los emigrantes de retorno en sus sociedades de origen han sido muy estudiados en regiones españolas como Asturias y Galicia. Pese a que León presenta patrones migratorios similares cualitativa y cuantitativamente, el proceso ha sido poco estudiado. Este artículo presenta una revisión bibliográfica de la investigación sobre migración leonesa. Igualmente, expone una investigación en la comarca de Maragatería, centrándose en el caso de Val de San Lorenzo, donde el impacto de la emigración fue enorme a finales del siglo XIX y principios del XX, lo que llevó a la creación de sociedades de emigrantes en Cuba y Argentina. El artículo analiza la sociedad establecida en Buenos Aires y cómo su actividad catalizó un proceso de aculturación en Val de San Lorenzo. La investigación combina metodologías históricas, antropológicas y estudios de cultura material para recabar datos diversos y ofrecer un análisis interdisciplinario. Igualmente, se conectan eventos pasados con contextos contemporáneos, subrayando las interacciones complejas entre grupos emigrantes y comunidades de origen y sus consecuencias a largo plazo. 